\title{
Citizenship education for Lesotho's context: Towards a stable democracy
}

Author:

Rasebate I. Mokotso ${ }^{1}$ (I)

\section{Affiliation:}

${ }^{1}$ Department of Religion Studies, University of the Free State, Bloemfontein, South Africa

Corresponding author: Rasebate Mokotso, rasebatemokotso@gmail.com

Dates:

Received: 10 Feb. 2018

Accepted: 19 Oct. 2018

Published: 13 May 2019

How to cite this article:

Mokotso, R.I., 2019,

'Citizenship education for Lesotho's context: Towards a stable democracy', The Journal for Transdisciplinary Research in Southern Africa 15(1), a549. https://doi. org/10.4102/td.v15i1.549

\section{Copyright:}

C) 2019. The Authors. Licensee: AOSIS. This work

is licensed under the

Creative Commons

Attribution License.

Read online:
This article represents a contextual analysis that seeks a lasting solution to Lesotho's current democratic instability, which has typified its political landscape since independence. This article analyses the literature to argue that the optimised political and institutional reforms that have recently raised people's hopes are not likely to bring about a lasting solution of democratic stability. They are likely to suffer the same fate as those that came before, which only managed to provide a temporary solution. This article contends that the sustainability of democracy in Lesotho can ideally be achieved through the cultivation of the 'spirit of democracy', which can be nurtured through citizenship education. The article concludes by exploring possibilities for the introduction of citizenship education in Lesotho.

Keywords: Citizenship education; democracy; Lesotho; politics; stability.

\section{Introduction}

Ever since Lesotho gained political independence from British colonial rule, followed by the ushering in of democratic dispensation in 1966, the country has never enjoyed stable democratic rule. It suffered a series of coups and attempted coups, political murders and high-profile assassinations, forcing a continued Southern African Development Community (SADC) intervention. At the same time, corruption, the embezzlement of public funds, poverty and unemployment rates continue to skyrocket. This situation calls for a staid introspection and critical exploration from all circles, in order to urgently respond. This article is, therefore, one such response, approaching the problem from an educational point of view, with particular reference to citizenship education.

This article cautiously approached an enquiry on Lesotho's political volatility through a systematic literature review. The operative definition of a systematic literature review is adopted from Okoli (2015) and Michie and Williams (2003). They define it as an investigative process that identifies, evaluates and interprets available and relevant published works to address the research questions of the topic under investigation. A systematic literature review depends solely on the works already published. The purpose is not simply to expand them but to systematically screen, approve and select the relevant information to be included in the review. This entails a scientific process of extracting appropriate information related to the topic of investigation from vast literature sources. The research topic provides the criterion for data selection, while research questions necessitate the evaluation and interpretation of data. The research questions that guided the evaluation, interpretation and synthesis of the information are as follows: what is causing the current democracy instability in Lesotho; what is the best sustainable solution; and how can that solution be instigated?

\section{Lesotho's political context}

The political context of Lesotho has recently become a prime concern for local, regional and international communities. The apparent assassination of the Lesotho army commander Khoantle Motšomotšo on 05 September 2017, which the SADC called an 'inexcusable, barbaric and heinous act', aggravated this concern (Aljazeera 2017; BBC 2017; News24 2017). As deplorable as the assassination was, it is the perpetuation of Lesotho's political milieu ever since the attainment of independence. Maleleka (2009) divides Lesotho's post-independence politics into four historical phases. The first phase represents a multiparty democracy (1966-1970); the second represents a one-party state (1970-1986); the third is a military dictatorship (1986-1993); and the last is the return of multiparty democracy in 1993, which is currently still in place, notwithstanding a shortlived 1994 palace coup that interrupted it. Since 2012, the multiparty rule has bred another recent period referred to as 'coalition phases'. The coalition government phases include the first coalition (2012-2015), the second coalition (2015-2017) and the third coalition (2017-present). 
Motsamai (2015) indicates that the beginning of Lesotho's political difficulties can be traced right from the inception of democracy in the second phase of the post-independence period. The Basutoland National Party (BNP), under the leadership of Chief Leabua Jonathan, narrowly won the first democratic elections of 1966 (Coleman 2015). Jonathan instantly became the first prime minister of independent Lesotho and remained steadfastly as such for 20 years. Motsamai (2015) and Hassan and Ojo (2002) illustrate that the beginning of political violence started with the second election of 1970 that was won by an opposition party - the Basotho Congress Party (BCP). However, Jonathan adamantly refused to step down, citing the questionable excuse of election irregularities, thereby nullifying the official election results. He declared a national state of emergency and continued to retain power by coup. In the event, Coleman (2015) notes that Jonathan's unlawful government suspended the constitution, dissolved the parliament, banned the opposition and introduced a series of political murders. The prominent opposition leaders were forced to flee the country into exile, where they eventually resorted to low-key guerrilla warfare.

Jonathan's authoritarian rule lasted up until 1986 (Coleman 2017), when Lesotho entered the third phase of the postindependence period. Hassan and Ojo (2002) assert that the general elections were ultimately called in 1985 because of mounting international and regional pressure for democratic rule in Lesotho. Allegedly, the BNP manipulated the election processes to the extent that only its candidates could stand for elections in all constituencies and ultimately were declared to have won the elections. These developments, as Hassan and Ojo (2002) fittingly describe, led to increased opposition against the government. The increasing opposition contributed to disunity within the army. Two groups were instantly formed, one supporting Colonel Sehlabo and the other supporting Major General Lekhanya. As Coleman (2015) and Hassan and Ojo (2002) mention, Lekhanya eventually toppled Jonathan's government in an army coup in 1986. Lekhanya succeeded in toppling Jonathan after he sourced the necessary support from the South African government. The functional relationships between Jonathan's government and the South African government had drastically deteriorated. It is believed that Jonathan continued to support the outlawed South African African National Congress cadres and Major General Lekhanya cordially agreed to sever ties with the African National Congress.

Lekhanya's dictatorship military regime, which marks the third phase of post-independence governance in Lesotho, suspended democracy and banned political activities (Hassan \& Ojo 2002). The military regime only declined in the late 1980s as a result of disagreements between Lekhanya and King Moshoeshoe II (Coleman 2015). Lekhanya had strategically drawn the king into the government to consolidate support from Basotho traditionalists who still offered their allegiance to the king. The king was ultimately sent into exile, and his elder son, Letsie III, replaced him. Simultaneously, Lekhanya was also losing support from the
South African government under President F.W. de Klerk, who moderated Lekhanya's relationship with the hard-line pro-apartheid forces (Hassan \& Ojo 2002). Western aid was also declining, pressuring Lekhanya to return governance to the civilians. Despite these pressures, Coleman (2015) reports that Lekhanya clung to power until Col. Elias Phisoane Ramaema led a group of senior military officers to overthrow him in 1991.

Ramaema's military government lifted political bans and prepared for general elections in 1993. Ramaema's intervention marked the fourth key phase of Lesotho politics, which represents the return of multiparty democracy (Coleman 2015). The BCP under the leadership of Ntsu Mokhehle emerged victorious, winning all the constituencies in the 1993 elections. Mokhehle had just returned to the politics of Lesotho after spending a prolonged period in exile (Coleman 2015). However, as Motsamai (2015) claims, the democratically elected government was not without problems. Shortly after the election, a fierce battle broke out between two factions of the army: the one pro-BNP and the other pro-BCP. The war culminated in the assassination of Deputy Prime Minister Selometsi Baholo. In 1994, the democratic government was overthrown by King Letsie III in what is described as a palace coup. The king pushed for the reinstatement of his father, who was dethroned during Lekhanya's military government. The palace coup triggered widespread unrest and protests. The SACD was prompted to intervene and restore democracy. This intervention marked the beginning of continuous SADC involvement in Lesotho's politics (Motsamai 2015). In 1997, BCP suffered internal disputes over leadership roles, leading to a split. The BCP splinter Lesotho Congress for Democracy (LCD) was eventually formed in parliament under the leadership of Ntsu Mokhehle. The SACD Mokhehle led the LCD to victory in 1998. However, he was forced by illness to resign from politics, leaving the LCD leadership to Pakalitha Mosisili. Following the LCD victory, opposition parties refused to accept the election results and cried foul. The opposition resentment resulted in a military mutiny. The SADC restored stability through military intervention. This intervention caused widespread violence that left the capital Maseru and other urban cities half burnt (Motsamai 2015). The period between 1993 and 1998 was described as a time of consolidation of democracy. The country enjoyed a relatively stable democracy from 1998 to 2007 (Motsamai 2015).

As Monyane (2009) expounds, the LCD ruled the country until November 2006, when a popular cabinet minister, Tom Thabane, resigned to form a new political party - the Basotho Convention Centre (ABC). Thabane left the government together with a considerable number of LCD members of parliament. Prime Minister Mosisili was forced to request that King Letsie III dissolve parliament, and snap elections were called in 2007. Mosisili's LCD won the 2007 elections (Monyane 2009). The developments leading to the 2012 election followed the formation of an alternative political party in parliament in the same fashion as the LCD. Mosisili formed the Democratic Congress (DC), ending a 2-year-long 
factional battle and power struggles within the LCD. The DC took over the country's governance as the governing party until parliament was dissolved to pave the way for the 2012 elections (Monyane 2009). The 2012 elections, as Coleman (2017) explains, ended the 15 years of LCD as the one party ruling the country. Without a party with an outright victory, a coalition government was inevitable. The first coalition was comprised of the ABC, LCD and BNP. The leader of the ABC, Thabane, was appointed the prime minister of the coalition government and Metsing of the LCD became his deputy.

However, the 2012 coalition government, which barely lasted for 3 years, was characterised by an animated series of political events, resulting in political instability (Motsamai 2015). Motsamai (2015) identified some developments in the government that caused instability. Prime Minister Thabane appointed and dismissed government and parastate officials in key state institutions without the consent of his partners in government. These included the Independent Electoral Commission (IEC), the justice portfolios (Office of the Attorney General, the Director of Public Prosecutions), government secretaries and permanent secretaries, and police and military commanders. Motsamai (2015) believes these appointments and dismissals were politically motivated, and prompted sour relationships between Prime Minister Thabane and his deputy, Metsing. The direct result was the bombing of the homes of some high-ranking officials, an attempted military coup and prorogation of parliament. The problems were resolved by SADC intervention, with another snap election in 2015 (Coleman 2017).

Sejanamane (2016) articulates that the 2015 elections bred another coalition government of seven parties, including the DC and LCD as the leading parties in the coalition. Because there were a considerable number of parties forging the coalition, Weisfelder (2015) realised that pundits were tempted to render different names to it. The most popular were 'the coat of many colours' and '7de Laan', the latter a nickname from the popular South African soap opera. Mosisili came back to power as prime minister. Contrary to what Mosisili professed to have learned from Thabane's 'many blunders', that kept him from sustaining the coalition government for more than 5 years, Mosisili's coalition barely lasted for 2 years (Weisfelder 2015). Within these 2 years, the country was engulfed by different political problems. Sejanamane (2016) exemplified these problems including the flight of the three main opposition leaders. One of these included Thomas Thabane of the ABC, who fled to South Africa to escape murder threats. Another critical political problem was the murder of Lt Gen. Maaparankoe Mahao by his colleagues in the army. The SADC intervened and together with the government of Lesotho recommended the establishment of the Commission of Inquiry into Disturbances to National Peace and Stability in August 2015. The retired Botswanan judge Mphapi Phumaphi headed the commission. It was eventually named after him and referred to as the Phumaphi Commission (Sejanamane 2016). Sejanamane (2016) highlights that the work of the commission was primarily to investigate the circumstances leading to the death of Lt Gen. Maaparankoe Mahao on 25 June 2015, and the alleged mutiny plot in the Lesotho Defence Force (LDF). At the end, the commission released a report recommending, among others, that Lt Gen. Tlali Kamoli be relieved of command of the LDF; that members of the LDF who were suspects in cases of high treason be released; and that military officials involved in murder and other crimes pointed out in the report be suspended while their cases were investigated so they could be brought before the courts of law. However, as Sejanamane (2016) explicates, the coalition government did not accede to the recommendations, maintaining that in terms of Lesotho laws, the recommendations of the commission were not binding. The prime minister went further in a statement delivered in parliament that some of the recommendations may not see the light of day.

Apart from governance problems, there were internal problems within DC party structures, particularly between the party leader, Pakalitha Mosisili, and his deputy leader, Monyane Moleleki. There were rumours as early as the beginning of March 2015 that the DC deputy leader was in negotiations with the $\mathrm{ABC}$ and $\mathrm{BNP}$ leaders. It was said that he wanted to join them, along with some disgruntled members of parliament from the DC. This was barely a week after the formation of the seven-party coalition government (Mohloboli 2015). Mohloboli (2015) recounts that there were allegations that Moleleki and some DC parliamentarians were unhappy that Moleleki was not appointed as deputy premier. Instead, the Mosisili seven-party coalition had appointed Metsing to the deputy premiership as the leader of the second biggest party in the coalition government. Mohloboli (2015) claims that when confronted by the rumours, Moleleki had vehemently denied them as 'malicious rumours'. However, in the following year, by November 2016, an agreement was announced between the deputy leader of the DC, Monyane Moleleki, and Tom Thabane. They proclaimed that they had joined forces to remove Mosisili and install Moleleki as prime minister. As a result, Moleleki was suspended from the DC in December 2016. He eventually launched a new party, the Alliance of Democrats (AD), in January 2017 (Ntsukunyane 2017). Sejanamane (2017) elucidates that in January 2017, Moleleki crossed the floor in parliament with about $50 \%$ of the MPs, leaving Prime Minister Mosisili leading a minority coalition government. To aggravate the situation, Sejanamane (2017) asserts that the LCD, which was the second biggest after Mosisli's DC in the coalition government, was experiencing a split. The party's secretary general, Selibe Mochoboroane, launched a new party called the Movement for Economic Change. Mosisili's coalition was left with only 37 members of parliament out of 120. Mosisili resisted succumbing to Moleleki and Thabane's plan to form a government in parliament. As an alternative, he resorted to the dissolution of parliament and called for snap elections in June 2017. Mosisili's coalition partners lost dramatically in the elections, giving way to a third coalition government of four parties, namely Thabane's ABC, Moleleki's AD, Maseribane's BNP and Rantso's Reformed Congress of Lesotho. Thabane headed the coalition and was 
appointed the prime minister and Moleleki his deputy prime minister (Sejanamane 2017).

On 14 June 2017, two days before Thabane was to be sworn in as prime minister, his wife, Lipolelo Thabane, was murdered. Mokhethi (2017) postulates two theories regarding her murder that persist even today, with no breakthrough from police investigations. The first theory, which did not gain popularity, was the criminal theory that explains the murder as simply a criminal act. The most popular theory represents the political theory. The political theory was twofold: those sympathising with Thabane and the new coalition government accused the outgoing government of orchestrating the murder. It was argued the intention was to frustrate the new four-party alliance and cause doubts about its morality and credibility. It was also suggested that the incumbent government wanted to extend its tenure on the pretext of solving the murder case before the inauguration of the new prime minister. Those sympathetic to the outgoing coalition argued that Lipolelo was murdered by pro-Thabane supporters to eliminate her chances of reclaiming her rightful position as 'first lady'. Claiming her position as 'first lady' meant ousting Maisaiah, the current 'first lady' and Thabane's favourable wife. Lipolelo was deprived of this status in Thabane's initial term as prime minister in 2012, but won her position back through a court battle (Mokhethi 2017).

Three months after the death of Lipolelo, another murder shocked local, regional and international communities. The media was abuzz over the death of Lesotho army commander Lt Gen. Khoantle Motšomotšo (BBC 2017; Muzofa 2017; News24 2017). It was alleged that his subordinates, namely Lt Col. Hashatsi and Lt Col. Sechele, had assassinated him (Aljazeera 2017; Muzofa 2017). The key issues relating to the facts were unclear; one version of the story submits that the two soldiers had forced their way into Lt Gen. Motšomotšo's office, demanding to see him (BBC 2017; News24 2017). Another version claims that they were allowed to enter the army commander's office (Muzofa 2017; The Post 2017). It was reported that they were either on suspension or under investigation for the death of Lt Gen. Mahao (Muzofa 2017; The Post 2017). Following the version that they were allowed into the army commander's office, it becomes blurred as to how the suspended soldiers were permitted into the army commander's office carrying weapons. One was claimed to have had a gun, and the other a hand grenade. Furthermore, how would the people who had planned to assassinate someone carry out the operation without either of them wearing a bulletproof vest? It was reported that Motšomotšo's bodyguards ultimately killed the alleged assassins (Muzofa 2017; The Post 2017); as a result, the killers' side of the story could not be obtained.

Sejanamane (2017) alleges that Motšomotšo was eliminated because he had pledged allegiance to the new government and supported its commitment to implement the SADC recommendations captured in the Phumaphi Commission report. In line with the report, Motšomotšo had already told the army that all those implicated in criminal activity would have to face justice. Hashatsi and Sechele were implicated in the murder of Lt Gen. Mahao. According to Sejanamane (2017), Motšomotšo sent away three army officers suspected of the murder of one Lisebo Tang the day before his assassination. The two officers who murdered Motšomotšo purportedly accused him of selling them out to both the police and the government. The death of Motšomotšo resulted in the SADC deploying a Contingent Force into Lesotho. Its mission was to facilitate a secure, stable and peaceful environment conducive for the rule of law necessary for the implementation of SADC reforms (SADC 2017).

These brief political problems that have typified Lesotho may adequately explain the superficial understanding of democracy. This situation requires strategies to deepen the roots of democracy for the country's political stability.

\section{Attempts and failures to resuscitate Lesotho's democracy}

There have been different attempts to resuscitate Lesotho's fragile democracy. However, most of the hypothesised solutions were limited in time and scope. They were geared towards solving the immediate political problem. For example, Makoa (2004) traces the post-independence reforms, which were limited to the transition from colonial and chiefs' rule to a democratic government. These reforms were mainly in response to the agitations of the nationalists' political struggles of the time. These included parliamentary, electoral and monarchical reforms. Lesotho adopted the British Westminster parliamentary model of a pluralist, multiparty, competitive electoral system with a ceremonial monarchical role. However, the reforms failed to establish democratic rule because they were limited to the transitional period and focused mainly on political institutions. Makoa (2004) points to the signs of failure of the post-independence reforms. Between 1965 and 1966, King Moshoeshoe II led a campaign of civil disobedience aimed at unseating the legitimate democratic government. In consequence, the king incited the people to resist the newly democratic government, which he believed reduced him to a 'ghost' king. Additionally, Prime Minister Jonathan, of the new post-independence government, instigated antidemocratic governance policies. While it was expected that the role of the legitimately elected state was to defend the constitution and democracy, Makoa (2004) observed that, instead, Jonathan's government acted as an antidemocratic bulwark. For 23 years, from 1970 to 1993, Lesotho was under authoritarian rule. This undemocratic rule was characterised by brute force, oppression and one-party rule. Therefore, from its inception, democracy did not take root in Lesotho. The initial reforms were typically limited to the transitional period, with a limited scope focusing predominantly on political institutions and processes (Makoa 2004).

The year 1993 was idealised as the beginning of proper, democratic rule after legitimate elections enthroned Ntsu Mokhehle's BCP into power. Nonetheless, within a few months, democracy was hijacked in a palace coup. 
The situation prompted the SADC intervention (Maleleka 2009; Monyane 2009). Through its intervention, the SADC proposed several political reforms. Among them were the reinstatement of the BCP government and of King Moshoeshoe II, and the replacement of the director of elections with an IEC. The director of elections was an employee of the government and could undoubtedly be influenced by their employer. However, these reforms, as realised by Motsamai (2015), did not sustain democracy for long. In 1998, political riots and violence erupted. Monyane (2009) shows that before 1998, Lesotho used the first-past-the-post (FPTP) election model, or a 'winner takes all' system. The model provided an opportunity for one dominant party to form a parliament without opposition. In 1998, the LCD won 79 constituencies out of 80 , meaning it had secured 79 parliamentary seats. Realising its fate, the opposition, particularly the BCP and the BNP, protested the results, arguing that they were fraudulent. This was in spite of the fact that international observers proclaimed the elections free and fair (Monyane 2009). Motsamai (2015) states that the protesting parties mobilised their supporters to occupy Maseru in order to obstruct parliamentary sessions from commencing. The opposition insisted on the formation of a government of national unity. The legitimate governing party, the LCD, rejected the proposal. Failure to reach an agreement resulted in the opposition waging an armed protest, leading to weeks of political instability (Motsamai 2015).

The opposition's grievances, as Motsamai (2015) states, forced SADC intervention. It appointed the South African judge Pius Langa to investigate the credibility of the election results. His findings revealed that even though there were some irregularities, there was no electoral malpractice or fraud. The opposition refused to accept the findings, insisting that the king dissolve the parliament and call for fresh elections or establish a government of national unity. Some military mutineers supported the opposition course. They seized arms and ammunition and imprisoned their commanding officers. These developments led to SADC military intervention to restore order - but not political stability. Makoa (2004) notes that the SADC military intervention succeeded in restoring security stability and reinstating the LCD government on the condition that it prepare for fresh elections within 18 months. There was, in addition, the establishment of the multiparty Interim Political Authority (IPA), mandated to review the electoral process in preparation for the upcoming elections under SADC supervision. According to Motsamai (2015) and Matlosa (2003), IPA recommended a series of political reforms consisting of: (1) a new electoral model, the mixed member parallel (MMP) system, which is a composite of the FPTP and proportional representation electoral systems; (2) increasing the National Assembly from 80 seats to 120; (3) stipulating that the additional 40 seats were to be from a proportional representation, with each party providing a list of MPs proposed to represent the party in the National Assembly.

The introduction of the MMP system in the 2002 elections was envisaged to consolidate and sustain democracy. Its chief aim was to promote a 'general participative' democracy where even the more minor parties would be able to contribute to the governance of the country (Motsamai 2015). It is indisputed that post-2002 election reforms provided Lesotho with a relatively stable democracy. Nonetheless, it was just a matter of time before the reality of Lesotho's democratic fragility surfaced, perpetuating a culture of feigning democracy. As Motsamai (2015) indicates, the incompetence of Lesotho's democracy re-emerged in the 2007 elections after the ruling LCD garnered 61 of the 80 constituencies. The opposition parties refused to accept the election results. They argued that the LCD manipulated the MMP system through the creation of alliances to misrepresent the MMP's compensatory procedures. The SADC was forced to mediate the impasse for 3 years, from 2007 to 2009 . A final agreement between the opposition and the government was brokered in the Electoral Reform Act of 2011. According to Weisfelder (2015), unlike the initial MMP electoral system, voters simultaneously elected a local constituency candidate and the party's candidate for compensatory proportional representation on a single ballot. They no longer voted for a party other than that of the constituency candidate of their choice. In the same way, they voted for their preferred party if it did not have a constituency candidate. The 2011 reforms provided short-lived political stability. The peaceful transfer of power after the 2012 elections from Mosisili to Thabane and establishment of the first coalition government signified relative political stability.

However, Weisfelder (2015) shows that the 2011 reforms focused on settling MMP disputes, without anticipating the formation of coalition governments that would reshape Lesotho's democracy. Conflicts among coalition partners emerged as new threats to Lesotho's democracy. The first coalition of 2012 collapsed before it enacted the Commonwealth-suggested reforms. Commonwealth envoy Rajen Prasad's report outlined recommendations for institutional reforms. Prasad realised that partisan appointments of the civil and security services were crucial sources of conflicts among partners in the coalition. He therefore recommended the establishment of an independent professional civil service. The other recommended reform was the regulation of floor crossing in parliament, which continually undermines the sustainability of coalition governments. Returning to the previous two-ballot electoral system was also recommended (Weisfelder 2015). Just as the 2012 coalition collapsed before implementing Rajen Prasad's recommendations, the 2015 coalition followed suit before enacting the recommendations contained in the Phumaphi Commission report. This trend highlights the reality that political reforms are mainly reactive, responding to the immediate political impasse, rather than being proactive and aiming at lasting, stable democracy.

\section{The need for citizenship education for Lesotho's stable democracy}

In recent times, all expectations have rested on the implementation of Phumaphi's institutional and political reforms, with the hope that they will stabilise Lesotho's democracy. For example, Sejanamane (2016) is optimistic that 
the Phumaphi Commission offers the potential for a brighter political future for Lesotho because it focuses on constitutional, public sector and security reforms. Moreover, Dlamini-Zuma (2016), in her capacity as the chairperson of the African Union (AU), stated that all hope for Lesotho restoring its democracy is based on the reforms recommended by the SADC-sponsored Commission of Inquiry, led by Justice Mphaphi Phumaphi of Botswana. She, therefore, unreservedly recommends intense collaboration between the government and the people of Lesotho to hasten the implementation of the recommended reforms. The current prime minister of Lesotho, Thabane (2017), in his speech at the UN General Assembly, vowed that the current government is committed to the effective implementation of the recommendations of the Phumaphi Commission for the reform process. This encompasses the constitutional, parliamentary, electoral, public and security sectors in a move to establish stable democratic rule, which is conducive to economic development. The Transformation Resource Centre (2016) released a statement to be considered by the SADC Double Troika in Gaborone, Botswana, on 28 June 2016. It appealed to the SADC to call upon the government of Lesotho to implement the Phumaphi Commission's recommendations. The Transformation Resource Centre believes that the recommendations are likely to restore genuine democracy. The list could go on and on. However, it is the contention of this article that, like other previous institutional and constitutional reforms, the Phumaphi reforms are likely to follow a similar path to failure.

This article concurs with the findings of Makoa (2004) in that whatever institutional or constitutional reforms Lesotho may have, without the necessary ideological or political resources for the promotion of the nation's 'spirit' of democracy, stability is unlikely to be experienced any time soon. This democratic spirit can arguably only be cultivated through an education process that can produce a new Basotho society that understands and adheres to the values and principles of democracy. Political institutions and the constitution can exclusively work for the people when all accept that they represent the general moral binding and are willing to commit themselves to a set of rules underpinning the constitution and the institutions. In support, Maundeni (2010) argues that the problem of Lesotho's democracy does not lie within constitutional or electoral systems but in the culture of resisting and rejecting new ideologies that contradict traditional values. These include the longstanding attempts to reject Christianity and the continuation of accepting that political leaders are elected for life, as is the case with traditional leaders. Sotho culture, according to Maundeni (2010), jealously guards itself against the intrusion of foreign cultures; it maintains a society that is not open to renewal from borrowed ideas. A solution suggested by Maundeni (2010) represents the creation of an environment to enable Lesotho to come up with a cultural reorientation strategy to steer people out of traditionalism, with elements that are incompatible with Western democratic values. While Weisfelder (2014) commends the new MMP electoral system of Lesotho, which provides a legislature composition corresponding with national levels of support from different parties and acts as an effective remedy to the exclusionary electoral FPTP system, he contends that the challenge remains the promotion of better governance, greater accountability and more profound commitment to democratic values.

These views point to the fact that electoral, institutional and constitutional reforms are not enough to ensure a stable democracy in Lesotho. It is the position of this author that citizenship education represents one strategy with the potential to promote a sustainable democratic rule. Citizenship education can cultivate the spirit of democracy in Basotho youth. If Makoa (2004) is correct that the colonial government granted independence with an alreadyprescribed kind of state for Lesotho, imposing the alien phenomenon of Western-fashioned democracy without equipping the Basotho nation to address the challenges of independence through the inculcation of political and social values that foster democracy, then citizenship education remains the probable tool to fill the gap. If again, the hypothesis of Maundeni (2010) is correct, that Basotho culture is responsible for the failure of democracy in Lesotho, then citizenship education is imperative to re-orientate the traditional culture. Nieto (1999) reasoned that education is the best tool to re-orientate culture. Culture is embedded in context; that is, culture is invariably influenced by the environment in which it exists. Contextualisation of culture typically occurs in the school curriculum. Culture is not static; it is constantly evolving as human beings continually change it. We talk of the culture of failed democracy and the culture of political violence in Lesotho because there is at present a change of culture from traditional monarchical rule to unstable democracy. Nieto (1999) reasons that culture changes as a result of concrete decisions made by cultural agents in relation to traditions, attitudes, behaviours and values. Culture constructs cultural agents, and they in turn construct the culture. According to Nieto (1999), conscious cultural change occurs in a school setting.

\section{Conceptualisation and competences of citizenship education}

Cecchini (2004) and Tormey (2006) state that there is no consensus on the conceptualisation of citizenship education, leading to diverse nomenclature. Different terminologies for citizenship education include active citizenship, civic education, political education, citizenship learning, education for democratic citizenship, social education, human rights education, democracy learning, life skills and learning to live together. In this article, the concept of 'citizenship education' is used to differentiate it from its synonyms in Lesotho. There are already two types of synonymic citizenship education in Lesotho schools. The first is life skills education (LSE). As Khau (2012) states, LSE was introduced into Lesotho in 2007 to respond to the challenges of HIV/AIDS. The idea was that education would be likely to provide a 'vaccine' against HIV. As such, LSE was introduced essentially for sexual health education, with specific emphasis on sexuality 
and HIV/AIDS education. Kolosoa and Makhakhane (2010) agree as well that LSE was introduced in Lesotho schools as an educational strategy to curb the spread of HIV. It was also intended to address the problem of alcohol and drug abuse. It was therefore introduced basically as a social and health education. In this sense, therefore, Lesotho's LSE is not about the inculcation of values of democracy but socio-health issues.

The second type of citizenship education is electoral or voter education, which is essentially 'civic education'. Ngozwana (2014) states that in Lesotho, voter education was introduced as an informal education programme in 1997. It is provided as a periodic education programme offered at the time of general elections. The IEC officials, civil society groups and political parties' representatives are responsible for providing the electorate with voter education. Its content covers the registration information, nomination and voting processes. The methods of teaching include the use of posters, pamphlets, public notices, public gatherings, local radio and TV station announcements, and newspapers. The IEC is responsible for the preparation of teaching materials. Voter education does not develop the spirit of democracy but exclusively prepares citizens to exercise their civic nomination and voting rights in times of elections.

Furthermore, citizenship education is selected on the basis of debates in civic or citizenship education discourse. For example, Kerr (1999) postulates that citizenship education is an ideal constructed from civic education. Civic education takes a minimal approach, which narrowly focuses on transmission of knowledge of a country's historical and geographical information. It also focuses on election processes, political structures, the functioning of the government and the constitution. Civic education tends to employ didactic teaching and learning approaches in which a teacher transmits knowledge to the students, who passively absorb it. Civics presupposes the provision of information about formal public institutions, while citizenship includes the promotion of socially beneficial qualities and encourages a participative learning approach (Himmelmann 2013).

As Cecchini (2004) notes, the focus of citizenship education depends on each country's historical and political struggle. Mutch (2005) also supports the conclusion that citizenship education cannot be divorced from a country's political and historical antecedents. In addition, Kerr (1999) affirms that citizenship education is best understood in the context of democratic reforms. It emphasises the fact that all democratic societies are to respond to the ever-changing circumstances that challenge their stability. Therefore, in Lesotho's context, citizenship education should focus on democratic stability. It must be accepted as a process of reform for long-term stability and must focus on developing the spirit of democracy. In other words, it should be synonymous with 'democracy learning' or 'democracy literacy'. Print and Lange (2012) conclude that in the event that a nation's democracy is faced with the challenge of an inability to sustain itself, particularly in times of crisis, citizenship education that aims at advocating and inculcating democratic values and actions becomes critical. It is obvious that living democracy is neither inborn nor to be taken for granted. Like any culture, the democratic culture, of shared values and the common rules of society, needs to be transmitted and learned.

The type of citizenship education optimised for Lesotho's democratic stability is within the framework proposed by Himmelmann (2013) and Dürr (2005), which centres on democracy and its pedagogical concept. This kind of citizenship education focusses on three competences of learning and living democracy. These are 'democracy as a form of government', 'democracy as a form of society' and 'democracy as a form of living'. These different competences of democracy are learned at various levels of educational development involving a taxonomic procedure of beginning from the general to the abstract.

The focus of teaching and learning in democracy as a form of government is to provide students at the senior secondary level with sufficient knowledge and understanding of their national history, political and government structures, and their functions and responsibilities in relation to other local, regional and global entities (Dürr 2005; Himmelmann 2013). This aspect of citizenship learning is extremely important in Lesotho's context because there has been a series of institutional and political reforms and still others to come. However, the fundamental question is whether all Basotho, including youth and those at grass-roots level, are literate to them or whether they are the endeavours of political elites only. Literacy on political and government structures and their functions enable citizens to participate in reforms with a sound understanding of what they mean for democracy.

The emphasis on teaching and learning in democracy as a form of society offered to students at junior secondary level involves learning by doing. Learning by doing is enhanced through learners' active, participative experiences in the school area as well as in their local community and society. The aim is to enable learning through social interaction, promoting competences of social cooperation, communication, respecting others' views and choices, knowing one's rights and responsibilities, understanding pluralism and its principles, and being equipped with the necessary skills to manage conflict and to participatein conflict resolution(Dürr2005; Himmelmann 2013; Kerr 1999). Citizenship education promotes what Makoa (2004) describes as an aspect lacking in Lesotho's democracy, which are norms and structures that can neutralise continuous political competition. These norms can also increase social collaboration and cooperation, with expanded political participation as a national norm rather than using elections as justification for exclusivism. Citizenship education fosters the spirit of democracy, where intergroup interactions, free discussions and the exchange of ideas become idealised. It acts as an effective means for peaceful handling of deep-rooted differences through inclusivism, justice and accountability.

The aim of teaching and learning of democracy as a form of living is to provide pupils at the primary level with the principles of democracy as a way of life. The focus is on the individual, and 
the aim is to enable self-learning through the acquisition of selfcompetences including self-development, self-experience, selfresponsibility, self-control and moral dispositions. Democracy as a form of living enables young children to make a direct link between the learning process and their everyday life experiences (Dürr 2005; Himmelmann 2013). Self-competences are very important for cultural reorientation. Maundeni (2010) and Ngozwana (2014) posited that a deficiency and fragility of Lesotho's democracy is a result of the traditional political structure that assigns all powers to authorities. Modern liberal democracy tends to replace traditional structures of authority with elected leaders. As a result, Basotho are faced with clashes of political values between Western and traditional political organisations, without being equipped with the essential tools to merge the two or to replace the old with the new. Ngozwana (2014) advances that the political elites have been able to exploit traditional values of obedience to control the passive masses that respect and put their trust in political leaders as was the case with the chiefs. Living democracy as an educational strategy is intended to establish a new culture of politically participative citizens who are not merely passive recipients of authorities' regulatory systems.

\section{Citizenship education opportunities in Lesotho}

It can be concluded that both the political situation and the current state of the Lesotho education system offer some opportunities for the introduction of citizenship education as well as indicating that Lesotho is apt to be democratically stable. From a political point of view, there is a general concern that drastic measures have to be taken to ensure democratic stability in Lesotho. For example, Santho (2008) states that it is imperative to explore opportunities for sustainable democratic governance in Lesotho. Such opportunities should be founded on a firm base of tolerance of multiple views and perspectives from various societal groupings. In addition, Matlosa (2003) shares the concern that elections and the choice of electoral system are unlikely to produce good results of democratic governance if there is no sustainable peace and reconciliation. Therefore, alternative strategies have to be devised and employed to ensure the involvement of a broader spectrum of the electorate. Tsikoane et al. (2007) concur that to consolidate democracy in any country, the active participation of all citizens, both individually and collectively, should be promoted. It is the responsibility of a democratic state to ensure it creates an enabling environment in which there are open debates, persuasion and compromise.

Lehohla (2006), then deputy prime minister and minister of education in Lesotho, advances that Lesotho as a young fledgling democracy is committed to stabilising its democratic governance by adhering to the core principle of people's participation in political decisions. This commitment is enshrined in numerous government documents, including Vision 2020, which states that 'Lesotho shall be a stable, democratic, prosperous nation, at peace with itself and neighbours'. It is believed that education, more than anything else, remains a major weapon to overcome democratic ills like corruption. Young people need to be provided with appropriate knowledge, skills and attitudes to develop a civil and conscientious society. These few examples highlight that because the idea of identifying possible ways of enhancing stable democracy in Lesotho represents a commonly shared belief, citizenship education is likely to find support from various sectors and stakeholders.

In the Lesotho education system, there are two opportunities. The first is that citizenship education is already being offered in the school system through LSE. However, at present, the focus is to address health challenges, mainly HIV and AIDS. What is needed is to extend the scope of LSE to include citizenship education. Kolosoa and Makhakhane (2010) opine that even though LSE has been restricted to health issues, it can be expanded to include consumer education, environmental education, peace education or education for development, livelihood and income generation, and education for democracy, among others. Life skills education is essentially citizenship education; what is left is to inject competences for democracy.

Another subject into which citizenship education could be integrated is religious education. Religious education is one of the dominant subjects in the Lesotho education system because it is the identity of the Christian Church. According to the recent statistics by the US Department of State (2017), the Christian Church owns more than $80 \%$ of schools. However, as SetlobokoChokobane and Moshoeshoe (2003) contend, religious education in Lesotho has been underutilised. Instead of teaching social and political values of peace, tolerance, diversity, fairness, justice, equality and responsibility, which are essential elements of citizenship education, it is confined to Christian instruction. Leung Yat Sum (2010) maintains that religious education in pluralistic societies can no longer be Bible-based but must be centred on students' lives. Its concern should be the lives of students, and the role of the Bible is to provide witness and give meaning to citizens' lives. The teaching of religious values should serve as a source of reflection, a way to talk about life and as a reference for students. In this way, religious education can contribute towards the development of moral values attuned to citizenship education. Allowing the consideration that Lesotho has claimed to be a Christian country (US Department of State 2013), a citizenship education component within religious education is likely to diffuse rapidly.

Lesotho has introduced an integrated curriculum in primary schools and is piloting it in some selected secondary schools. The intention is to cover all schools within the next few years. The integrated curriculum offers an opportunity for citizenship education. Many proponents of citizenship education agree that it cannot be restricted to traditional, academically coined subjects. That is, it cannot merely be learned as an independent 'stand-alone' subject. Kerr (1999) mentions three approaches to the teaching and learning of citizenship education, namely the separate approach, the integrated approach and the crosscurricular approach. In the separate approach, citizenship education is delivered as a specific subject. In the integrated 
approach, it is offered within broad disciplines of social sciences or social studies, which could be linked to other subjects and curricular areas. In the cross-curricular approach, citizenship education goes beyond both the separate approach and integrated approach to permeate the entire curriculum and become infused into all school subjects. However, the separate approach has not gained favour. For example, Beutel (2012), Burton (2015) and Veugelers (2011) argue that citizenship education prepares people to accept that only democracy can offer them a stable, social and liberal society. It also enriches society's ability to resist the undemocratic behaviours of intolerance, racism, xenophobia and violence. Therefore, these diverse problems cannot only be dealt with in a single school subject. The integrated curriculum introduced in Lesotho provides fertile soil for the germination and growth of citizenship education.

\section{Acknowledgements \\ Competing interests}

The author declares that he has no financial or personal relationships which may have inappropriately influenced him in writing this article.

\section{References}

Aljazeera, 2017, Lesotho army commander 'shot dead' by soldiers, 5 September viewed 12 December 2017, from http://www.aljazeera.com/news/2017/09/ lesotho-army-commander-shot-dead-soldiers-170905132409306.html

BBC, 2017, SADC condemns the killing of Lesotho army chief Khoantle Motsomotso, 6 September, viewed 12 December 2017, from http://www.bbc.com/news/ world-africa-41173999

Beutel, W., 2012, 'Developing civic education in schools', in M. Print \& M. Dirk Lange (eds.), Schools, curriculum and civic education for building democratic citizens, pp. 7-18, Sense Publishers, Rotterdam.

Burton, D., 2015, 'Citizenship education in secondary schools in England', Journal of the British Education Studies Association 7(1), 76-91.

Cecchini, M., 2004, 'Education for democratic citizenship in Europe: Concepts and challenges for action', Paper presented at Networking European Citizenship Education (NECE) conference, 27 November, pp. 1-11.

Coleman, D.Y. (ed.), 2015, Lesotho - CountryWatch country reviews, CountryWatch, Inc., TX, viewed 17 December 2017, from http://www.countrywatch.com

Coleman, D.Y. (ed.), 2017, Lesotho - CountryWatch country reviews, CountryWatch, Inc, TX, viewed 17 December 2017, from http://www.countrywatch.com

Dlamini-Zuma, N., 2016, AU expresses concern over political developments in the Kingdom of Lesotho, Directorate of Information and Communication, Addis Ababa.

Dürr, K., 2005, The school: A democratic learning community, Landeszentrale für Politische Bildung, Baden-Württemberg.

Hassan, F.M.A. \& Ojo, O., 2002, Lesotho development in a challenging environment: A joint World Bank-African Development Bank evaluation, The International Bank for Reconstruction and Development/The World Bank, Washington, DC

Himmelmann, G., 2013, 'Competences for teaching, learning and living democratic citizenship', in M. Print \& D. Lange (eds.), Civic education and competences for engaging citizens in democracies, pp. 3-8,, Sense Publishers, Rotterdam.

Kerr, D., 1999, 'Citizenship education: An International comparison', Internationa Review of Curriculum and Assessment Frameworks Archive, viewed 02 December 2017, from www.inca.org.uk/thematic.asp

Khau, M., 2012, 'Sexuality education in rural Lesotho schools: Challenges and possibilities', Sex Education: Sexuality, Society and Learning 12(4), 411-423.

Kolosoa, C.L. \& Makhakhane, B., 2010, Life skills for national development in Lesotho: Can $O D L$ do it?, Institute for Development Management and the National University of Lesotho, Maseru.

Lehohla, A.L., 2006, 'Lesotho country paper', Paper presented at the international seminar Strategies to improve transparency and accountability in education organised by IIEP in collaboration with the Mexican Secretariat of Basic Education, in Guanajuato, Mexico, 03-07 November.

Leung Yat Sum, E., 2010, 'Religious studies as moral and civic education: A brief review of its past development, future opportunities and challenges', Hong Kong Teachers' Centre Journal 9, 16-26.

Makoa, F.K., 2004, 'Electoral reform and political stability in Lesotho', African Journa on Conflict Resolution 4(2), 79-96.
Maleleka, D., 2009, The impact of democracy in Lesotho: Assessing political, social and economic developments since the dawn of democracy, Centre for Policy Studies, Johannesburg.

Matlosa, K., 2003, 'The electoral process and democratic governance in Lesotho. Lessons for the Democratic Republic of Congo', Journal of African Elections 2(1), 77-98. https://doi.org/10.20940/JAE/2003/v2i1a7

Maundeni, Z., 2010, 'Political culture as a source of political instability: The case of Lesotho', African Journal of Political Science and International Relations $4(4), 128-139$.

Michie, S. \& Williams, S., 2003, 'Reducing work-related psychological ill health and sickness absence: A systematic literature review', Occupational and Environmental Medicine 60, 3-9. https://doi.org/10.1136/oem.60.1.3

Mohloboli, K., 2015, 'Moleleki taunts "terrified enemies"', Lesotho Times, 26 March, viewed 21 December 2017, from http://www.lestimes.com/moleleki-tauntsterrified-enemies

Mokhethi, S., 2017, Murder of Thabane's wife in Lesotho a can of worms, viewed 19 December 2017, from https://www.africanindy.com/news/murder-ofthabanes-wife-in-lesotho-a-can-of-worms-9802274

Monyane, C., 2009, 'The kingdom of Lesotho: An assessment of problems in democratic consolidation', PhD thesis, Department of Political Science, Stellenbosch University.

Motsamai, D., 2015, 'Elections in a time of instability: Challenges for Lesotho beyond the 2015 poll', Institute for Security Studies 3, 1-14, viewed 21 December 2017, from www.issafrica.org

Mutch, C., 2005, 'Citizenship education: Does it have a place in the curriculum?', Curriculum Matters 1, 49-70.

Muzofa, N., 2017, 'How Motšomotšo was killed', Lesotho Times, 7 September, viewed 15 December 2017, from http://www.lestimes.com/how-motsomotso-was-killed

News24, 2017, SADC: Killing of Lesotho army chief 'an inexcusable barbaric and heinous act', viewed 12 December 2017, from http://www.news24.com/Africa/News/sadckilling-of-lesotho-army-chief-an-inexcusable-barbaric-and-heinous-act-20170906

Ngozwana, M., 2014, 'Understandings of democracy and citizenship in Lesotho: Implications for civic education', Unpublished PhD thesis, Faculty of Education, University of KwaZulu-Natal.

Nieto, S., 1999, The light in their eyes: Creating multicultural learning communities, Teachers College Press, New York.

Ntsukunyane, L., 2017, 'ABC-AD in new elections deal', Lesotho Times, 28 January, viewed 11 December 2017, from http://www.lestimes.com/abc-ad-in-new-elections-deal

Okoli, C., 2015, 'A guide to conducting a standalone systematic literature review', Communications of the Association for Information Systems 34(43), 879-910. https://doi.org/10.17705/1CAIS.03743

Print, M. \& Lange, D., 2012, 'Introduction', in M. Print \& D. Lange (eds.), Schools, curriculum and civic education for building democratic citizens, Sense Publishers, Rotterdam.

Southern African Development Community (SADC), 2017, 'SADC officially launches the SADC preventive mission in the Kingdom of Lesotho', SADC Media Release,
02 December 2017, from https://www.sadc.int/news-events/news. p. 1

Santho, S., 2008, 'Prospects for the promotion of a culture of political tolerance in Lesotho. Special issue: Elections and democracy in Lesotho', Journal of African Elections 7(1), 66-74. https://doi.org/10.20940/JAE/2008/v7i1a4

Sejanamane, M.M., 2016, Lesotho crisis: Can SADC Unblock the Logjam?, viewed 20 December 2017, from https://lesothoanalysis.com/2016/10/17/fear-anddesperation-in-lesothos-amnesty-bill-futile-attempts-to-legitimise-murder

Sejanamane, M.M., 2017, Mosisili's last desperate moves: Strategy of 'ruling from the grave', viewed 20 December 2017, from https://lesothoanalysis.com/2017/01/06/ mosisilis-last-desperate-moves-strategy-of-ruling-from-the-grave

Setloboko-Chokobane, M. \& Moshoeshoe, M.B., 2003, 'Religious tolerance and citizenship in Lesotho: Religious education or citizenship education', in A. Osman \& B. Leibowitz (eds.), A framework for heritage, multiculturalism and citizenship education, pp. 73-78, Commonwealth Secretariat, London.

Thabane, M.T., 2017, 'Statement by the right honorable the Prime Minister of the Kingdom of Lesotho', delivered at the 72 nd Session of the United Nations General Assembly New York, United States of America, 22 September.

The Post, 2017, How army boss was killed, 11 September, viewed 20 December 2017, from https://www.thepost.co.Is/news/how-army-boss-was-killed

Tormey, R., 2006, Social and political education in senior cycle: A background paper Department of Education and Professional Studies, University of Limerick, Limerick, Ireland.

Transformation Resource Centre, 2016, Position of the Transformation Resource Centre on the outcome of the SADC Double Troika in Gaborone, Botswana, on 28 June 2016, Press Statement, Maseru.

Tsikoane, T., Tefetso H., Mothibe, T.H., Ntho, M.E. \& Maleleka, D., 2007, 'Consolidating democracy governance in Southern Africa: Lesotho', EISA Research Report 23,
$1-110$, viewed 15 November 2017, from https://www.africaportal.org/ 1-110, viewed 15 Novem
documents/1845/rr32.pdf

United States Department of State, 2013, Lesotho 2013 International Religious Freedom Report, Bureau of Democracy, Human Rights and Labor.

United States Department of State, 2017, Lesotho 2017 International Religious Freedom Report, Bureau of Democracy, Human Rights and Labor.

Veugelers, W., 2011, 'Theory and practice of citizenship education: The case of policy, science and education in the Netherlands', Revista de Educación, Número Extraordinario 357, 209-224.

Weisfelder, R.F., 2015, 'Free elections and political instability in Lesotho', Journal of African Elections 14(2), 50-80. https://doi.org/10.20940/JAE/2015/v14i2a3 